\title{
Alpha-Lipoic Acid Suppresses Extracellular Histone-Induced Release of the Inflammatory Mediator Tumor Necrosis Factor- $\alpha$ by Macrophages
}

\author{
Ping Chang ${ }^{a}$ Juan Liu ${ }^{a}$ Ying Yu ${ }^{a}$ Shao-Ye Cui ${ }^{a}$ Zhen-Hui Guo ${ }^{b}$ \\ Gui-Ming Chen ${ }^{\mathrm{a}}$ Qiong Huang ${ }^{\mathrm{a}}$ Zhan-Guo Liu \\ aDepartment of Intensive Care Unit, Zhujiang Hospital, Southern Medical University, Guangzhou, \\ ${ }^{b}$ Guangdong Provincial Key Laboratory of Geriatric Infection and Organ Function Support, Department \\ of Medical Intensive Care Unit, General Hospital of Guangzhou Military Command, Guangzhou, China
}

\section{Key Words}

Extracellular histones $\cdot \mathrm{ALA} \cdot \mathrm{TNF}-\alpha \cdot \mathrm{MAPKs} \cdot \mathrm{NF}-\mathrm{KB} \cdot$ Macrophages

\begin{abstract}
Background/Aims: This study investigated signaling pathways via which extracellular histones induce the pro-inflammatory cytokine tumor necrosis factor- $\alpha$ (TNF- $\alpha$ ) release from the macrophage cell line RAW 264.7 and the anti-inflammatory efficacy of the antioxidant alpha-lipoic acid (ALA). Methods: ELISA and western blotting analyses were conducted to detect the release of TNF- $\alpha$ from histone-stimulated RAW 264.7 macrophages and the associated phospho-activation of MAPKs (ERK and p38) and NF-KB p65. The effects of ALA on the release of TNF- $\alpha$ and phospho-activation of the MAPKs and NF-KB p65 were studied. $\mathrm{P}<0.05$ was considered statistically significant. Results: Extracellular histones dosedependently induced TNF- $\alpha$ release from RAW 264.7 cells and increased the phosphorylation of $\mathrm{p} 38$, ERK, and NF-KB p65. TNF- $\alpha$ release was markedly suppressed by $\mathrm{p38}$, ERK, and NF$\kappa B$ inhibitors. ALA reduced histone-induced TNF- $\alpha$ release, ERK/p38 MAPK activation, and $N F-\kappa B$ activation without affecting macrophage viability. Conclusion: Histones induce TNF- $\alpha$ release from macrophages by activating the MAPK and NF- $\kappa B$ signaling pathways, while ALA suppresses this response by inhibiting ERK, p38 and NF- $\kappa B$. These findings identify potentially critical inflammatory signaling pathways in sepsis and molecular targets for sepsis treatment.
\end{abstract}

\section{Introduction}

(C) 2017 The Author(s)

Published by S. Karger AG, Basel

Sepsis treatment is a major challenge in intensive care medicine [1, 2]. In the United States, approximately 750, 000 cases of sepsis occur every year, resulting in over 200, 000 deaths [3]. Sepsis is associated with uncontrolled inflammation, which can lead to multiple organ dysfunction syndrome (MODS) [4]. Pro-inflammatory mediators such as tumor 


\section{Cellular Physiology Cell Physiol Biochem 2017;42:2559-2568

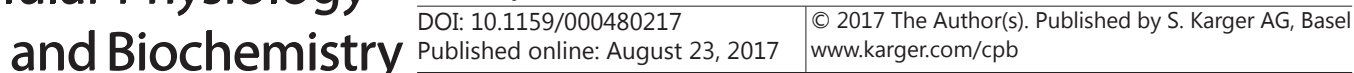 \\ Chang et al.: Suppression of Macrophage TNF- $\alpha$ Production by Alpha-Lipoic Acid}

necrosis factor- $\alpha$ (TNF- $\alpha$ ), interferon- $\gamma$ (IFN- $\gamma$ ), and interleukin-2 (IL-2) are involved in the induction and progression of sepsis. Serum TNF- $\alpha$ concentrations substantially increase during the early phase of sepsis $[5,6]$ and trigger a spectrum of pathogenic processes, particularly the induction and release of additional pro-inflammatory cytokines that further amplify the early inflammatory response. TNF- $\alpha$ is critical in the development of MODS in animal models of sepsis $[7,8]$. Macrophages play an important role in immune response and inflammation [9-13]. In sepsis, macrophages participate in the progression of uncontrolled inflammation and development of SIRS and MODS [14-17] by acting as the main source of pro-inflammatory cytokines, including TNF- $\alpha[18]$.

Recently, the contribution of extracellular histones in sepsis has attracted considerable attention. Histone release can cause endothelial damage, cell apoptosis, and organ failure through inflammation and mitochondrial injury [19-22]. Extracellular histones are derived from dying tissues [23] or dying neutrophils within neutrophil extracellular traps [24] during host defense to bacterial infections. Histones induce the release of TNF- $\alpha$, IL-1 $\beta$, IL-6, and IL10 , while pre-incubation with a histone $\mathrm{H} 4$ neutralization antibody protects against these pro-inflammatory responses [25, 26]. Mitogen-activated protein kinase (MAPK) signaling pathways, including extracellular signal-regulated kinase (ERK) and p38 pathways, are key mediators in inflammatory transduction and amplification [27].

Alpha-lipoic acid (ALA), which is an endogenous antioxidant widely used as a nutritional supplement, was first isolated from bovine liver in the 1950s [28] and is considered to be a potential vitamin. However, ensuing studies have shown that ALA, which exists in mitochondrial enzymes, functions as a cofactor in biological oxidation reactions $[29,30]$. As a multifunctional antioxidant, ALA can improve disease symptoms by reducing the production of oxygen free radicals [31-34]. Zhang et al. found that ALA reduces lipopolysaccharide (LPS)-induced inflammatory responses in human monocytes by activating the PI3K/AKT signaling pathway [35]. Moreover, ALA prolongs survival and attenuates inflammatory responses in a rat model of sepsis by blocking the activation of the NF- $\kappa B$ pathway [36]. However, the signaling pathways via which extracellular histones mediate inflammation and those underlying the anti-inflammatory effects of ALA are unclear. In the present study, we utilized RAW 264.7 cells, a widely used murine-derived macrophage cell line, to investigate the signal pathway via which extracellular histones mediate inflammation and the antiinflammatory efficacy of ALA.

\section{Materials and Methods}

\section{Materials}

Cell culture medium (Dulbecco's modified Eagle's medium, DMEM) was purchased from HyClone Laboratories (Logan, UT, USA). All antibodies were purchased from Cell Signaling Technology (Danvers, MA, USA). All other agents were purchased from Sigma (St. Louis, MO, USA).

\section{Cell culture medium and reagent preparation}

DMEM was supplemented with $10 \%$ fetal bovine serum (FBS) and 1\% penicillin/streptomycin and was stored in a refrigerator at $4^{\circ} \mathrm{C}$ for the experiments. Total histones derived from the calf thymus were dissolved in phosphate-buffered saline (PBS; $10 \mathrm{mg} / \mathrm{ml}$ ) for the experiments.

\section{Cell culture and reagents}

The murine macrophage cell line RAW 264.7 (American Type Culture Collection) was cultured in DMEM containing $10 \%$ fetal bovine serum and $1 \%$ penicillin/streptomycin at $37^{\circ} \mathrm{C}$ under a humidified $5 \%$ $\mathrm{CO}_{2}$ atmosphere. Prior to the study, RAW 264.7 cells were detached using $0.25 \%$ trypsin and cultured in six-well plates at $1 \times 10^{6}$ cells per well. Total histones derived from the calf thymus were dissolved in PBS $(10 \mathrm{mg} / \mathrm{mL})$ for the experiments. RAW 264.7 cells were treated with various concentrations of histones $(0,10,25$, and $50 \mu \mathrm{g} / \mathrm{mL})$ for a set time $(12 \mathrm{~h})$ or were treated with a set concentration of histones $(50 \mu \mathrm{g} /$ $\mathrm{mL}$ ) for various times $(0,20,30,45,60$, and $120 \mathrm{~min})$. After incubation, cells were collected for analyzing 


\section{Cellular Physiology Cell Physiol Biochem 2017;42:2559-2568

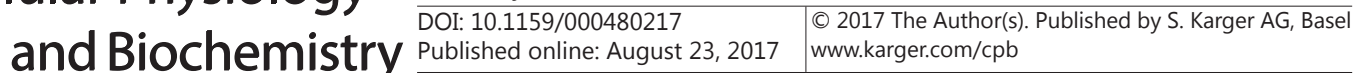 \\ Chang et al.: Suppression of Macrophage TNF- $\alpha$ Production by Alpha-Lipoic Acid}

the release of TNF- $\alpha$ and phosphorylation of p38, ERK, and p65.Then, the supernatants were harvested for TNF- $\alpha$ measurement by ELISA. RAW 264.7 cells were treated with various concentrations of ALA $(0,50$, and $100 \mu \mathrm{g} / \mathrm{mL}$ ) or various concentrations of histones (25 and $50 \mu \mathrm{g} / \mathrm{mL})$ for a set time $(14 \mathrm{~h})$, and cell viability was measured using the 3-(4,5-dimethyl-2-thiazolyl)-2,5-diphenyl-2-H-tetrazolium bromide (MTT) and Cell Counting Kit-8 (CCK-8) assay. After that, ALA (50 $\mu \mathrm{g} / \mathrm{mL})$ with or without histones (50 $\mu \mathrm{g} / \mathrm{mL})$ were used to treat cells for $12 \mathrm{~h}$; then, the cells were collected for analyzing release of TNF- $\alpha$ and phosphorylation of p38, ERK, and p65.

ELISA

TNF- $\alpha$ was quantified in culture media using a TNF- $\alpha$ ELISA kit (ExCell Biology, Shanghai, China) according to the manufacturer's instructions.

\section{Western blotting}

Whole-cell extracts were prepared from treated RAW 264.7 cells to investigate the expression levels of various cell signaling molecules and their phosphorylated (activated) forms. Briefly, following the treatment was indicated: cells were washed 3 times with cold PBS and incubated on ice for $30 \mathrm{~min}$ in a cell lysis buffer supplemented with protease and phosphatase inhibitors. The whole-cell lysate was centrifuged at $10000 \times \mathrm{g}$ for $10 \mathrm{~min}$ at $4^{\circ} \mathrm{C}$ and the supernatant was collected. Supernatant samples were diluted 1:4 in a $5 \times$ loading buffer and heated to $100^{\circ} \mathrm{C}$ for $10 \mathrm{~min}$. Equal quantities of whole-cell protein were separated by SDS-PAGE and transferred to polyvinylidene difluoride membranes. Membranes were blocked with 5\% nonfat milk in TBST [20 mM Tris-HCL,15 mM NaCl, 0.05\% (v/v) Tween-20 (pH 7.4)] for $1 \mathrm{~h}$ at room temperature (RT), washed 3 times with TBST (5 min/wash), and blotted with antibodies against phospho-p38 (1:2000 dilution), phospho-ERK (1:2000), phospho-NF-кB p65 (phospho S276) antibody (1:2000), p38 (1:1000), ERK (1:1000), or p65 (1:1000) at $4^{\circ} \mathrm{C}$ overnight. Blotted membranes were washed 3 times with TBST (15 min/wash), incubated with secondary antibodies at RT for $1 \mathrm{~h}$, and washed 3 times with TBST (15 min/ wash). Immobilon Chemiluminescent HRP substrate (ECL) was used to detect immunolabeled proteins. Band intensities were quantified by the AlphaEase FC software (Alpha Innotech, San Leandro, CA, USA). The target protein band density was normalized to that of GADPH as the internal gel loading control.

Cell viability assays

Cell viability was assessed using the MTT and CCK-8 assays. Briefly, RAW 264.7 cells were seeded in 96-well plates at $1 \times 10^{4}$ cells per well, cultured for $14 \mathrm{~h}$, and then treated with ALA. After the removal of the culture media, the cells were incubated with an MTT working solution $(5 \mathrm{mg} / \mathrm{mL})$ at $37^{\circ} \mathrm{C}$ for $4 \mathrm{~h}$ and then with $150 \mu \mathrm{L}$ DMSO to dissolve the formazan crystals arising from MTT metabolism by viable cells. Finally, absorbance at $490 \mathrm{~nm}$ was read on an absorbance microplate reader to estimate the viable cell number. The procedure used for the CCK-8 assays was similar, except the absorbance, which was read at $450 \mathrm{~nm}$.

\section{Statistical analysis}

Results are expressed as mean \pm standard error (SE). All data were analyzed using one-way analysis of variance (ANOVA), and multiple comparison between the groups was performed using the S-N-K method on the SPSS software system (version 20.0; SPSS Inc., Chicago, IL). A P $<0.05$ was considered statistically significant.

\section{Results}

Extracellular histones induced TNF- $\alpha$ release from $R A W 264.7$ cells

Extracellular histones induced TNF- $\alpha$ release from RAW 264.7 macrophages in a dosedependent manner, with the release rate increasing by more than 10 -fold over the tested concentration range $(\mathrm{P}<0.05)$ (Fig. 1).

Extracellular histones activated the ERK and p38 pathways

Concomitant with this increase in TNF- $\alpha$ release, extracellular histones rapidly upregulated the expression of phosphorylated (activated) ERK and p38, two major transducers of inflammatory signaling in macrophages [37, 38]. Increased phosphorylation 
Fig. 1.Extracellular histones induce TNF- $\alpha$ released from macrophages. TNF- $\alpha$ concentrations in the RAW 264.7 cell culture media were measured using ELISA after treatment with 0, 10, 25, or 50 $\mu \mathrm{g} / \mathrm{mL}$ extracellular histones for $12 \mathrm{~h} .{ }^{*} \mathrm{P}<0.05$ and $* * \mathrm{P}<0.01$ compared to $0 \mu \mathrm{g} / \mathrm{mL}$ (control).
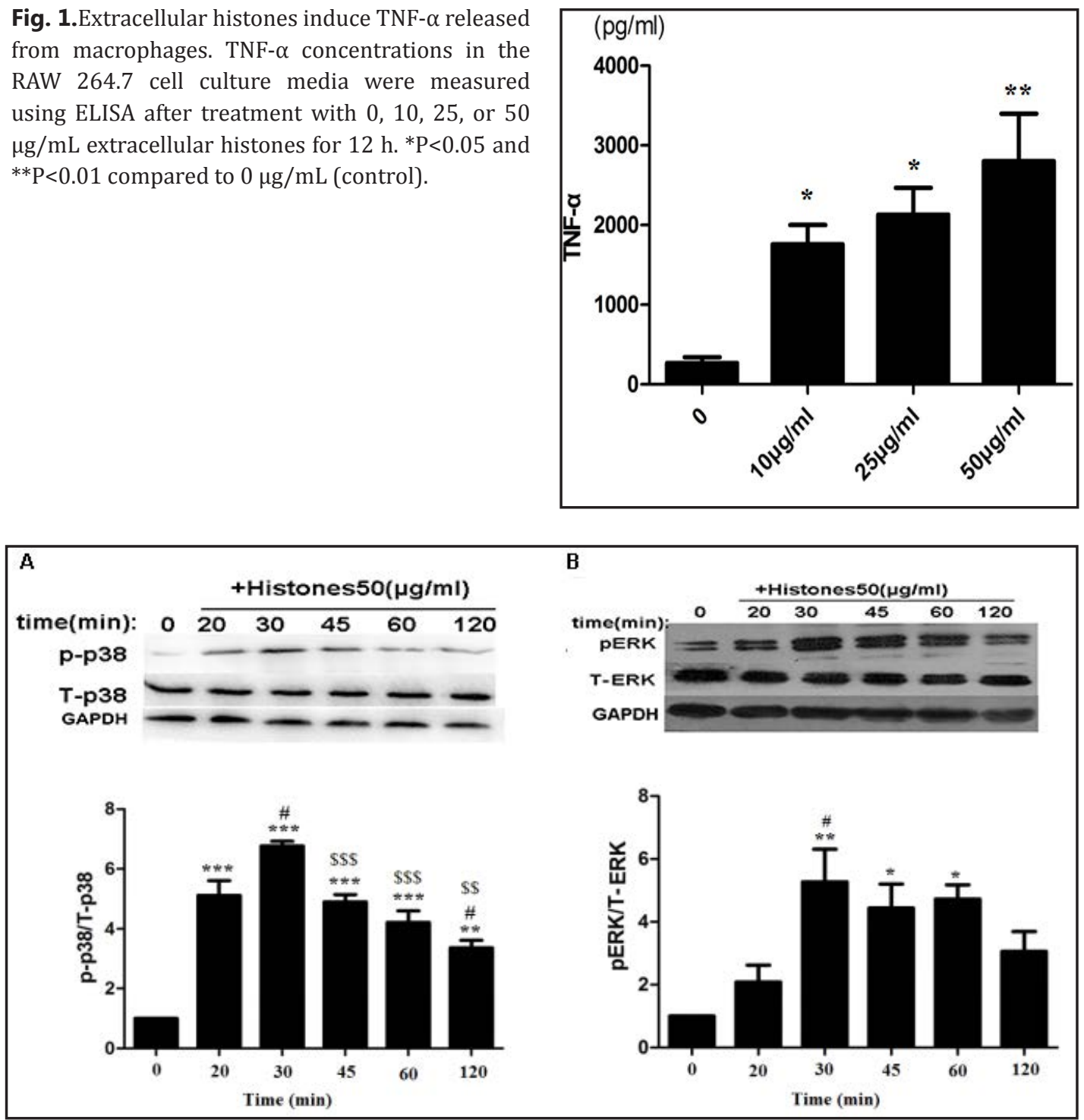

Fig. 2. Extracellular histones activate the ERK and p38 signaling pathways in macrophages. RAW 264.7 cells were cultured with extracellular histones $(50 \mu \mathrm{g} / \mathrm{mL})$ for the indicated times. (A, B) Phosphorylation levels of p38 (A) and ERK (B) were measured using western blots (upper panels) and quantified using densitometry (lower panels). (A) Time-dependent increase in phosphorylated p38 (p-p38) expression relative to total p38 (T-p38) during histone treatment. (B) Time-dependent increase in phosphorylated ERK (p-ERK) expression relative to total ERK (T-ERK) during histone treatment. GAPDH was used as the gel loading control. ${ }^{*} \mathrm{P}<0.05,{ }^{* *} \mathrm{P}<0.01$, and ${ }^{* * *} \mathrm{P}<0.001$ compared to $0 \mathrm{~min}$ (control); ${ }^{*} \mathrm{P}<0.05$ compared to 20 min; ${ }^{\$} \mathrm{P}<0.01$ and ${ }^{\$ \$} \mathrm{P}<0.001$ compared to $30 \mathrm{~min}$.

of ERK and p38 was observed after as little as 20 min of histone treatment, with phosphoactivation peaking at $30 \mathrm{~min}$ (Fig. 2). This result suggests that MAPK activation is an important early event in histone-induced pro-inflammatory signaling by macrophages.

\section{Extracellular histones induced $N F-\kappa B$ activation}

The NF- $\kappa$ B pathway plays an important role in sepsis-related inflammation [39, 40]. To determine whether the NF- $\kappa \mathrm{B}$ pathway is involved in the histone-induced upregulation of TNF- $\alpha$ release from RAW 264.7 cells, we measured the phosphorylation levels of the NF- $\kappa B$ subunit p65, which promotes NF- $\kappa B$ transcriptional activity at multiple levels. Extracellular 


\section{Cellular Physiology Cell Physiol Biochem 2017;42:2559-2568 and Biochemistry \begin{tabular}{c|c} 
DOI: 10.1159/000480217 & $\begin{array}{l}\text { O 2017 The Author(s). Published by S. Karger AG, Basel } \\
\text { www.karger.com/cpb }\end{array}$
\end{tabular}

Fig. 3. Extracellular histones activate NF-kB in macrophages. RAW 264.7 cells were cultured with extracellular histones (50 $\mathrm{\mu g} / \mathrm{mL}$ ) for the indicated times. Western blotting (top) was utilized to examine the phosphorylation of NF- $\mathrm{KB} /$ p65. Bottom panel: Densitometry showing phosphorylated NF- $\mathrm{B}$ subunit p65 (pp65) relative to total NF- $\kappa B / p 65$ (T-p65). GAPDH expression was used as the gel loading control. ${ }^{*} \mathrm{P}<0.05$ and ${ }^{* * *} \mathrm{P}<0.001$ compared to $0 \mathrm{~min}$; ${ }^{\#} \mathrm{P}<0.05$ and ${ }^{\# \# \#} \mathrm{P}<0.05$ compared to $45 \mathrm{~min} ;{ }^{\$ \$} \mathrm{P}<0.001$ compared to $60 \mathrm{~min}$.

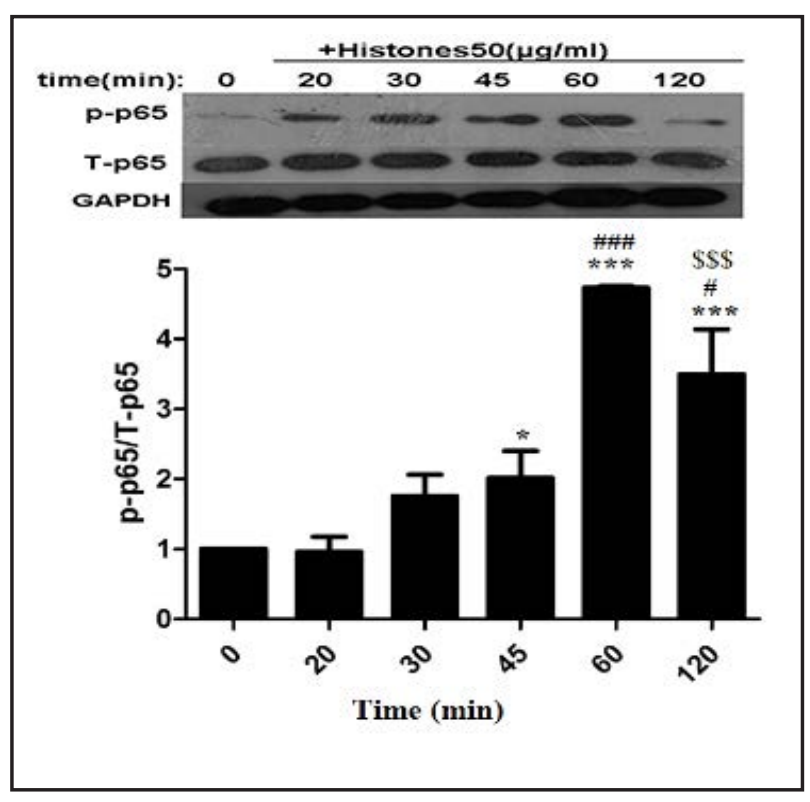

Fig. 4. Extracellular histone-induced TNF- $\alpha$ release from RAW 264.7 macrophages is dependent on MAPK and NF- $\kappa$ B pathway activation. RAW 264.7 cells were pretreated with the p38 inhibitor SB203580 (10 $\mu \mathrm{mol} / \mathrm{mL})$, ERK inhibitor PD98059 $(10 \mu \mathrm{mol} / \mathrm{ml})$, or NF- $\kappa$ B inhibitor PDTC $(10 \mu \mathrm{mol} /$ $\mathrm{mL}$ ) for $1 \mathrm{~h}$. After $12 \mathrm{~h}$ incubation with extracellular histones (His, $50 \mu \mathrm{g} / \mathrm{mL}$ ), the supernatants were harvested for TNF- $\alpha$ measurements by ELISA. ${ }^{* * *} \mathrm{P}<0.001$ compared to the control group; ${ }^{\# \#} \mathrm{P}<0.01$ and ${ }^{\# \# \#} \mathrm{P}<0.001$ compared to the histone (His)-only group.

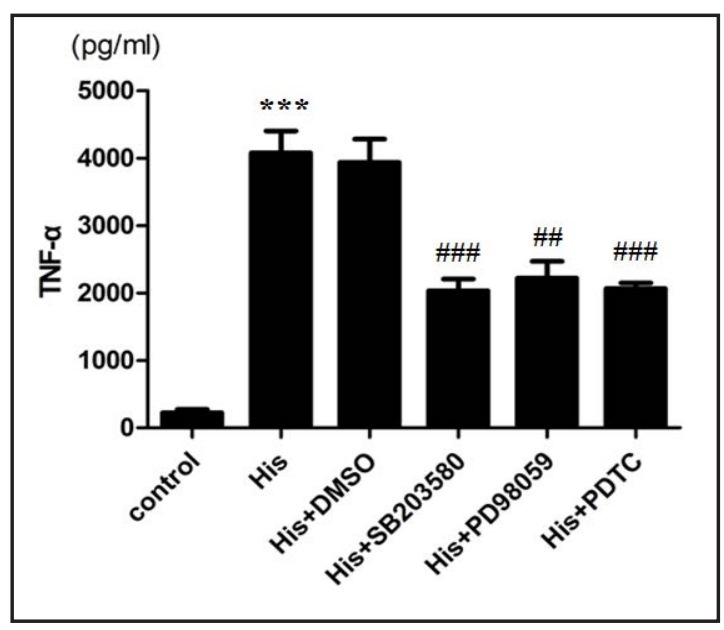

histones induced the phosphorylation of NF-kB p65 after 30 min of stimulation (Fig. 3), peaking at $60 \mathrm{~min}$.

\section{Extracellular histones induced TNF- $\alpha$ release via the MAPK and NF- $\kappa B$ pathways}

To examine if the histone-induced upregulation of TNF- $\alpha$ release and activation of ERK, p38, and NF- $\kappa$ B are related, we measured histone-induced TNF- $\alpha$ release under the targeted inhibition of each pathway. All three pathway inhibitors tested significantly reduced the histone-induced upregulation of TNF- $\alpha$ release compared to the histone alone group (p38 inhibitor SB203580: $2219.38 \pm 431.64$ pg/mL, ERK inhibitor PD98059: $2030.61 \pm 306.26$ $\mathrm{pg} / \mathrm{mL}, \mathrm{NF}-\kappa \mathrm{B}$ inhibitor PDTC: $2121.29 \pm 155.98 \mathrm{pg} / \mathrm{mL}$ vs. histones alone: $4078.93 \pm 558.02$ $\mathrm{pg} / \mathrm{mL}, \mathrm{P}<0.01$ ), while the inhibitor vehicle (DMSO) had no significant effect $(3935.35 \pm$ $602.34 \mathrm{pg} / \mathrm{mL}$ vs. $4078.93 \pm 558.02 \mathrm{pg} / \mathrm{mL}, \mathrm{P}>0.05$ ). These data suggest that the ERK, $\mathrm{p} 38$, and NF- $\kappa$ B pathways are involved in histone-induced TNF- $\alpha$ release (Fig. 4).

ALA suppressed TNF- $\alpha$ release without affecting cell viability

ALA had little effect on the viability of RAW 264.7 cells (P > 0.05) (Fig. 5A) at a dose $(50 \mu \mathrm{g} / \mathrm{mL})$ that significantly reduced histone-induced TNF- $\alpha$ release compared with TNF- $\alpha$ release in macrophages not subjected to ALA treatment $(2122.18 \pm 523.44 \mathrm{pg} / \mathrm{mL}$ vs. 
Fig. 5. ALA suppresses histoneinduced TNF- $\alpha$ release from RAW 264.7 cells without affecting cell viability. (A) RAW 264.7 cells were cultured with $\operatorname{ALA}(0,50$, or $100 \mu \mathrm{g} / \mathrm{mL})$ for 14 h. Cell viability was measured by the MTT assay. (B) RAW 264.7 cells were incubated with ALA (50 $\mu \mathrm{g} / \mathrm{mL}$ ) for $1 \mathrm{~h}$, followed by extracellular histone stimulation for $12 \mathrm{~h}$. TNF- $\alpha$ release into the medium was measured by ELISA. (C) RAW 264.7 cell viability was measured by the CCK-8 assay. $\quad * * * \mathrm{P}<0.001 \quad$ compared to the control group; ${ }^{\# \# P<0.01}$ compared to the histone (His)only group.

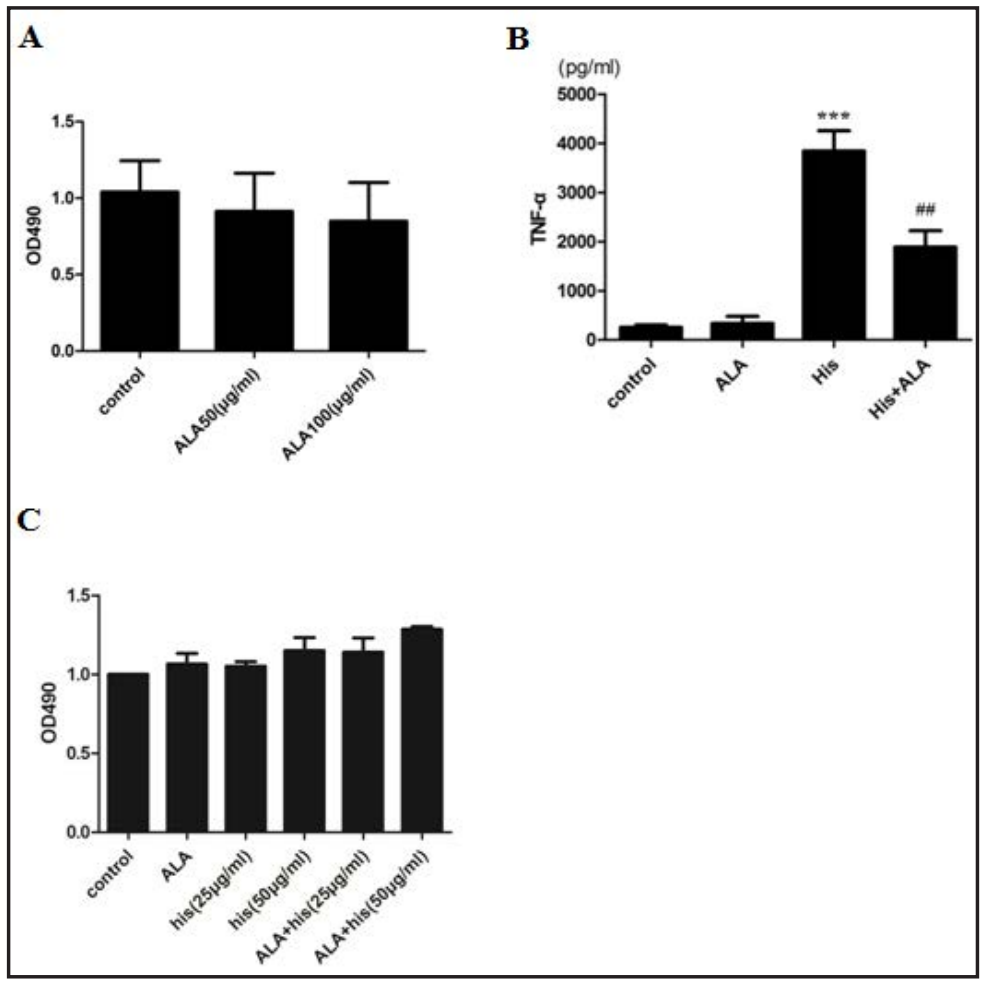

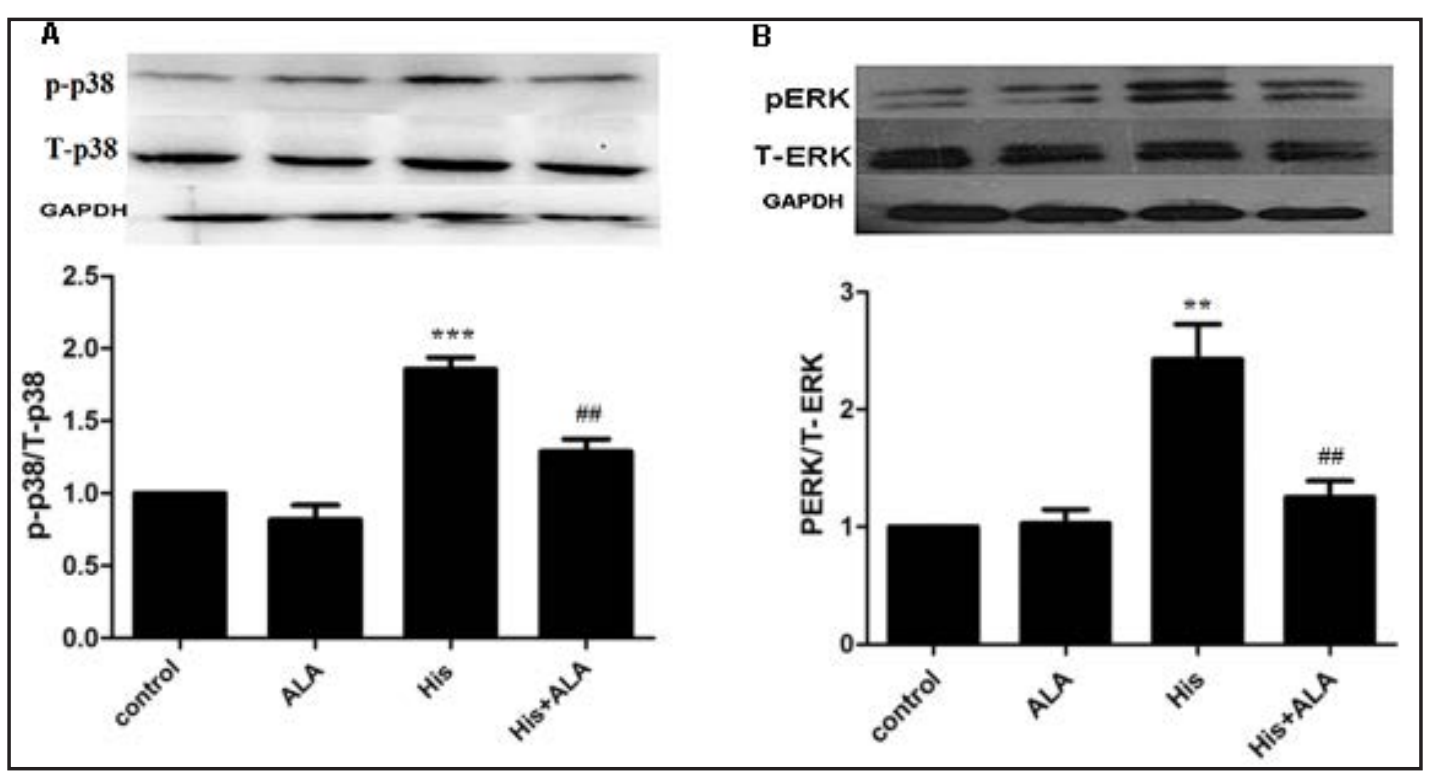

Fig. 6. ALA reduces histone-induced ERK and p38 activation in RAW 264.7 macrophages. RAW 264.7 cells were treated with ALA $(50 \mu \mathrm{g} / \mathrm{mL})$ for $1 \mathrm{~h}$ at $37^{\circ} \mathrm{C}$ before stimulation with extracellular histones $(50 \mu \mathrm{g} / \mathrm{mL})$ for 30 min. Phosphorylated p38 (p-p38) (A) and ERK (p-ERK) (B) were measured by western blotting (upper panels) and densitometry (lower panels) relative to total p38 (T-p38) and ERK (T-ERK), respectively. GADPH was used as the gel loading control. ${ }^{* *} \mathrm{P}<0.01$ and ${ }^{* * *} \mathrm{P}<0.001$ compared to the control group; ${ }^{\# \#} \mathrm{P}<0.01$ and

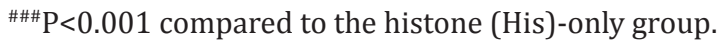

$3673.00 \pm 482.01 \mathrm{pg} / \mathrm{mL}, \mathrm{P}<0.05$ ) (Fig.5B). Thus, ALA is well tolerated by RAW 264.7 cells within the effective anti-inflammatory dose range (Fig. 5C). 


\section{Cellular Physiology

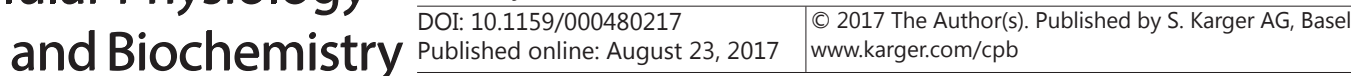 \\ Chang et al.: Suppression of Macrophage TNF- $\alpha$ Production by Alpha-Lipoic Acid}

Fig. 7. ALA reduces histone-induced NF- $\kappa B$ activation in RAW 264.7 cells. RAW 264.7 cells were treated with ALA $(50 \mu \mathrm{g} / \mathrm{mL})$ for $1 \mathrm{~h}$ at $37^{\circ} \mathrm{C}$ before stimulation with extracellular histones $(50 \mu \mathrm{g} / \mathrm{mL})$ for $60 \mathrm{~min}$. Phosphorylation of the NF- $\mathrm{B}$ subunit p65 (p-p65) was measured by western blotting (upper panel) and densitometry (lower panel) relative to total NF- $\mathrm{kB} / \mathrm{p} 65$ (T-p65). GADPH was used as the gel loading control. ${ }^{*} \mathrm{P}<0.05$ compared to the control group; ${ }^{*} \mathrm{P}<0.05$ compared with the histone (His)-only group.

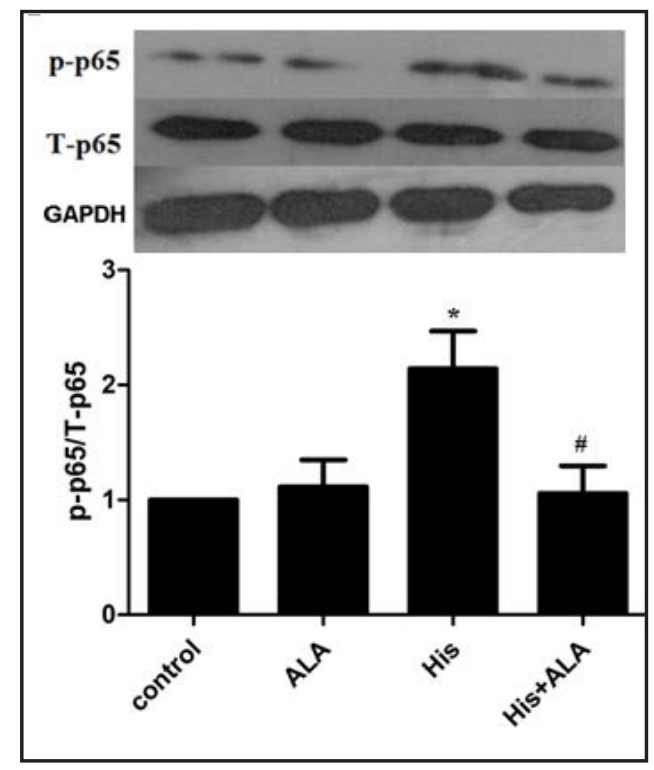

ALA reduced the histone-induced phosphorylation of ERK and p38 in RAW 264.7 cells

Concomitant with the reduction in histone-induced TNF- $\alpha$ release, ALA markedly reduced the histone-induced activation of the p38 pathway (Fig. 6A) and ERK pathway (Fig. 6B). Given that the histone-induced upregulation of TNF- $\alpha$ release is dependent on the phospho-activation of these signaling pathways (Fig. 4), it appears likely that the antiinflammatory effects of ALA are mediated by the inhibition of MAPK signaling.

ALA reduced histone-induced NF- $\kappa B$ p 65 phosphorylation in RAW 264.7 cells

Furthermore, ALA reduced NF- $\kappa B$ activation by inhibiting p65 phosphorylation (Fig. 7). Considering the NF- $\kappa B$-dependence of histone-induced TNF- $\alpha$ release from RAW 264.7 cells (Fig. 4), it appears that ALA reduced TNF- $\alpha$ release by suppressing NF- $\kappa B$ transcriptional activity (Fig.7).

\section{Discussion}

The present study showed that histones dose-dependently accelerated TNF- $\alpha$ release from RAW 264.7 cells, a response that was blocked by MAPK antagonists; this finding is consistent with MAPK involvement in inflammatory diseases such as septic shock $[37,38]$. Kawano et al. reported that extracellular histones trigger the production of IL-8 and IL- 6 by the human retinal epithelium cell line ARPE-19 through MAPK pathways [41]. Extracellular histones induced the phosphorylation of p38 and ERK in RAW 264.7 murine macrophages concomitant with elevated TNF- $\alpha$ release, and a specific p38 inhibitor and an ERK inhibitor each reduced histone-induced TNF- $\alpha$ release by approximately $50 \%$.

The transcription factor NF- $\kappa B$ is an essential downstream regulator of the inflammatory processes [40]. Allam et al. reported that extracellular histones induce IL- 6 and TNF- $\alpha$ production via the NF- $\kappa B$ pathway in dendritic cells [24]. Similarly, histones induce NF- $\kappa B$ p 65 phosphorylation concomitant with enhanced TNF- $\alpha$ release from RAW 264.7 macrophages, and this release is markedly reduced by an NF- $\mathrm{KB}$ inhibitor.

ALA is an endogenous antioxidant with potent anti-inflammatory effects [31-35]. Ha et al. reported that ALA suppresses inflammation by reducing COX-2 activity and PGE2 production [42]. Yamada et al. reported that ALA reduces inducible nitric oxide synthase expression in pro-inflammatory cytokine-stimulated hepatocytes [43]. However, the mechanisms underlying these anti-inflammatory effects are not well understood. We confirmed that extracellular histone-induced TNF- $\alpha$ release was mediated via the MAPK 


\section{Cellular Physiology

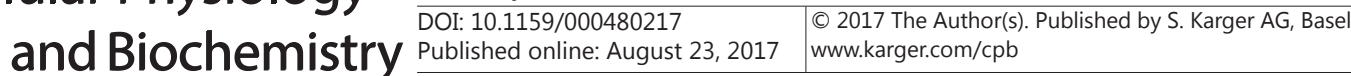 \\ Chang et al.: Suppression of Macrophage TNF- $\alpha$ Production by Alpha-Lipoic Acid}

Fig. 8. Schematic of the anti-inflammatory effects of ALA. Extracellular histones activate MAPK and $N F-\kappa B$ pathways to promote TNF- $\alpha$ synthesis and release. ALA can inhibit these signaling pathways, thereby reducing TNF- $\alpha$ production.

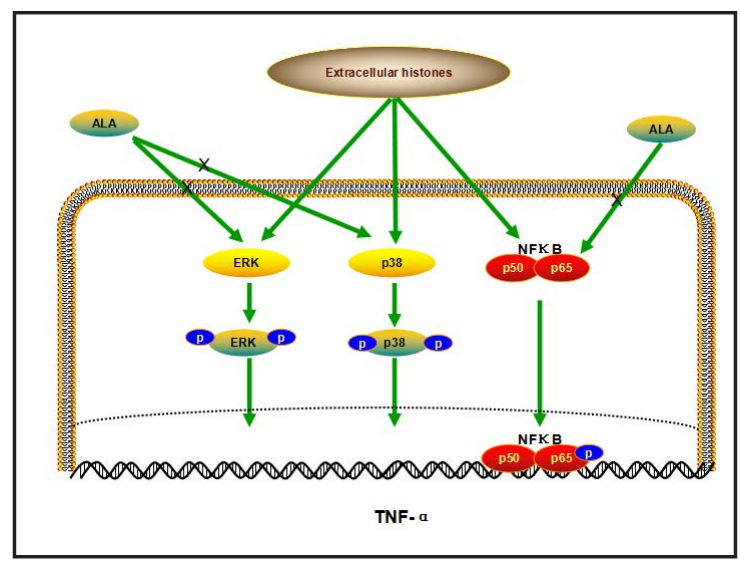

and NF- $\kappa$ B pathways and that ALA can significantly reduce TNF- $\alpha$ release in parallel with the suppression of the MAPK and NF- $\kappa B$ pathways. These effects on the phosphorylation (activation) of ERK, p38, and NF- $\kappa \mathrm{B}$ p65 are consistent with previous studies in human aortic endothelial cells [44] and LPS-stimulated rat mesangial cells [36]. Notably, ALA reduced this pro-inflammatory response at doses that did not markedly affect cell viability.

\section{Conclusion}

In summary, we demonstrated that extracellular histones can induce TNF- $\alpha$ release from RAW 264.7 cells and that this release is dependent on the activation of the p38, ERK, and NF- $\kappa B$ pathways. Further, we showed that ALA can reduce macrophage TNF- $\alpha$ release by inhibiting these pathways (Fig. 8). These findings identify ERKs, p38, and NF- $\kappa B$ as critical signaling factors in sepsis progression by mediating histone-induced macrophage TNF- $\alpha$ release and can be used for developing a treatment method for sepsis in the future. However, the presented results must be carefully interpreted owing to possible differences between primary and cultured macrophages. Nonetheless, further studies on ALA efficacy in animal models of sepsis, MODS, and SIRS are warranted.

\section{Acknowledgements}

This work was supported by grants from the National Natural Science Foundation for Youth of China (81101451), Science and Technology Planning Project of Guangdong Province (2013B021800147), Science and Technology Program of Guangzhou (2014J4100133), and Youth Talent Foundation of Zhujiang Hospital. The funders had no role in study design, data collection and analysis, decision to publish, or preparation of the manuscript.

\section{Disclosure Statement}

The authors declare that there is no conflict of interests.

\section{References}

1 Levy MM, Dellinger RP, Townsend SR, Linde-Zwirble WT, Marshall JC, Bion J, Schorr C, Artigas A, Ramsay G, Beale R, Parker MM, Gerlach H, Reinhart K, Silva E, Harvey M, Regan S, Angus DC: The surviving sepsis campaign: Results of an international guideline-based performance improvement program targeting severe sepsis. Intensive Care Med 2010;36:222-231. 


\section{Cellular Physiology Cell Physiol Biochem 2017;42:2559-2568 \begin{tabular}{l|l} 
DOI: 10.1159/000480217 & Ond Biochemistry \\
Published online: August 23, 2017 & $\begin{array}{l}\text { 2017 The Author(s). Published by S. Karger AG, Basel } \\
\text { www.karger.com/cpb }\end{array}$ \\
\cline { 2 - 3 }
\end{tabular}

2 Martin GS, Mannino DM, Eaton S, Moss M: The epidemiology of sepsis in the united states from 1979 through 2000. N Engl J Med 2003;348:1546-1554.

3 Marik PE: Surviving sepsis: Going beyond the guidelines. Ann Intensive Care 2011;1:17.

4 Polat G, Ugan RA, Cadirci E, Halici Z: Sepsis and septic shock: Current treatment strategies and new approaches. Eurasian J Med 2017;49:53-58.

-5 Kocabas E, Sarikcioglu A, Aksaray N, Seydaoglu G, Seyhun Y, Yaman A: Role of procalcitonin, c-reactive protein, interleukin-6, interleukin-8 and tumor necrosis factor-alpha in the diagnosis of neonatal sepsis. Turk J Pediatr 2007;49:7-20.

-6 Kumar S, Rizvi M: Serum tumor necrosis factor alpha and c-reactive protein in pediatric patients with sepsis and its correlation with microbiologic findings. Indian J Pathol Microbiol 2010;53:494-497.

7 Tracey KJ, Fong Y, Hesse DG, Manogue KR, Lee AT, Kuo GC, Lowry SF, Cerami A: Anti-cachectin/tnf monoclonal antibodies prevent septic shock during lethal bacteraemia. Nature 1987;330:662-664.

-8 Tracey KJ, Lowry SF, Fahey TJ, 3rd, Albert JD, Fong Y, Hesse D, Beutler B, Manogue KR, Calvano S, Wei H, et al.: Cachectin/tumor necrosis factor induces lethal shock and stress hormone responses in the dog. Surg Gynecol Obstet 1987;164:415-422.

-9 Chen W, Li Z, Guo Y, Zhou Y, Zhang Z, Zhang Y, Luo G, Yang X, Liao W, Li C, Chen L, Sheng P: Wear particles promote reactive oxygen species-mediated inflammation via the nicotinamide adenine dinucleotide phosphate oxidase pathway in macrophages surrounding loosened implants. Cell Physiol Biochem 2015;35:1857-1867.

-10 Gou Z, Jiang S, Zheng C, Tian Z, Lin X: Equol inhibits lps-induced oxidative stress and enhances the immune response in chicken hd11 macrophages. Cell Physiol Biochem 2015;36:611-621.

11 Li C, Ding XY, Xiang DM, Xu J, Huang XL, Hou FF, Zhou QG: Enhanced m1 and impaired m2 macrophage polarization and reduced mitochondrial biogenesis via inhibition of amp kinase in chronic kidney disease. Cell Physiol Biochem 2015;36:358-372.

12 Yang S, Li F, Jia S, Zhang K, Jiang W, Shang Y, Chang K, Deng S, Chen M: Early secreted antigen esat-6 of mycobacterium tuberculosis promotes apoptosis of macrophages via targeting the microrna155-socs1 interaction. Cell Physiol Biochem 2015;35:1276-1288.

13 Zhou Y, Zhang T, Wang X, Wei X, Chen Y, Guo L, Zhang J, Wang C: Curcumin modulates macrophage polarization through the inhibition of the toll-like receptor 4 expression and its signaling pathways. Cell Physiol Biochem 2015;36:631-641.

14 Ayala A, Urbanich MA, Herdon CD, Chaudry IH: Is sepsis-induced apoptosis associated with macrophage dysfunction? J Trauma 1996;40:568-573; discussion 573-564.

15 Lu MC, Liu TA, Lee MR, Lin L, Chang WC: Apoptosis contributes to the decrement in numbers of alveolar macrophages from rats with polymicrobial sepsis. J Microbiol Immunol Infect 2002;35:71-77.

16 Luan YY, Dong N, Xie M, Xiao XZ, Yao YM: The significance and regulatory mechanisms of innate immune cells in the development of sepsis. J Interferon Cytokine Res 2014;34:2-15.

17 Peck-Palmer OM, Unsinger J, Chang KC, McDonough JS, Perlman H, McDunn JE, Hotchkiss RS: Modulation of the bcl-2 family blocks sepsis-induced depletion of dendritic cells and macrophages. Shock 2009;31:359366.

18 Gordon S: The macrophage: Past, present and future. Eur J Immunol 2007;37:S9-17.

19 Liu ZG, Ni SY, Chen GM, Cai J, Guo ZH, Chang P, Li YS: Histones-mediated lymphocyte apoptosis during sepsis is dependent on 38 phosphorylation and mitochondrial permeability transition. PLoS One 2013;8:e77131.

20 Wen Z, Liu Y, Li F, Ren F, Chen D, Li X, Wen T: Circulating histones exacerbate inflammation in mice with acute liver failure. J Cell Biochem 2013;114:2384-2391.

-21 Xu J, Zhang X, Pelayo R, Monestier M, Ammollo CT, Semeraro F, Taylor FB, Esmon NL, Lupu F, Esmon CT: Extracellular histones are major mediators of death in sepsis. Nat Med 2009;15:1318-1321.

22 Zhang Y, Wen Z, Guan L, Jiang P, Gu T, Zhao J, Lv X, Wen T: Extracellular histones play an inflammatory role in acid aspiration-induced acute respiratory distress syndrome. Anesthesiology 2015;122:127-139.

-23 Allam R, Scherbaum CR, Darisipudi MN, Mulay SR, Hagele H, Lichtnekert J, Hagemann JH, Rupanagudi KV, Ryu M, Schwarzenberger C, Hohenstein B, Hugo C, Uhl B, Reichel CA, Krombach F, Monestier M, Liapis H, Moreth K, Schaefer L, Anders HJ: Histones from dying renal cells aggravate kidney injury via tlr2 and tlr4. J Am Soc Nephrol 2012;23:1375-1388. 


\section{Cellular Physiology Cell Physiol Biochem 2017;42:2559-2568 \begin{tabular}{l|l} 
DOI: 10.1159/000480217 23,2017 & $\begin{array}{l}\text { O 2017 The Author(s). Published by S. Karger AG, Basel } \\
\text { www.karger.com/cpb }\end{array}$
\end{tabular} \\ Chang et al.: Suppression of Macrophage TNF- $\alpha$ Production by Alpha-Lipoic Acid}

24 Papayannopoulos V, Zychlinsky A: Nets: A new strategy for using old weapons. Trends Immunol 2009;30:513-521.

25 Li X, Gou C, Yao L, Lei Z, Gu T, Ren F, Wen T: Patients with hbv-related acute-on-chronic liver failure have increased concentrations of extracellular histones aggravating cellular damage and systemic inflammation. J Viral Hepat 2017;24:59-67.

-26 Li X, Li Q Li J, Li Y, Chen Y, Lv A, Zhang J, Ding J, Von Maltzan K, Wen T: Elevated levels of circulating histones indicate disease activity in patients with hand, foot, and mouth disease (hfmd). Scand J Infect Dis 2014;46:818-824.

27 Guha M, Mackman N: Lps induction of gene expression in human monocytes. Cell Signal 2001;13:85-94.

-28 Reed LJ, De BB, Gunsalus IC, Hornberger CS Jr: Crystalline alpha-lipoic acid; a catalytic agent associated with pyruvate dehydrogenase. Science 1951;114:93-94.

29 Goraca A, Huk-Kolega H, Piechota A, Kleniewska P, Ciejka E, Skibska B: Lipoic acid - biological activity and therapeutic potential. Pharmacol Rep 2011;63:849-858.

30 Packer L, Witt EH, Tritschler HJ: Alpha-lipoic acid as a biological antioxidant. Free Radic Biol Med 1995;19:227-250.

31 Evans JL, Goldfine ID: Alpha-lipoic acid: A multifunctional antioxidant that improves insulin sensitivity in patients with type 2 diabetes. Diabetes Technol Ther 2000;2:401-413.

-32 Hegazy SK, Tolba OA, Mostafa TM, Eid MA, El-Afify DR: Alpha-lipoic acid improves subclinical left ventricular dysfunction in asymptomatic patients with type 1 diabetes. Rev Diabet Stud 2013;10:58-67.

33 Saygin M, Asci H, Cankara FN, Bayram D, Yesilot S, Candan IA, Alp HH: The impact of high fructose on cardiovascular system: Role of alpha-lipoic acid. Hum Exp Toxicol 2016;35:194-204.

34 Zhao L, Hu FX: Alpha-lipoic acid treatment of aged type 2 diabetes mellitus complicated with acute cerebral infarction. Eur Rev Med Pharmacol Sci 2014;18:3715-3719.

-35 Zhang WJ, Wei H, Hagen T, Frei B: Alpha-lipoic acid attenuates lps-induced inflammatory responses by activating the phosphoinositide 3-kinase/akt signaling pathway. Proc Natl Acad Sci U S A 2007;104:40774082.

-36 Li G, Fu J, Zhao Y, Ji K, Luan T, Zang B: Alpha-lipoic acid exerts anti-inflammatory effects on lipopolysaccharide-stimulated rat mesangial cells via inhibition of nuclear factor kappa b (nf-kappab) signaling pathway. Inflammation 2015;38:510-519.

37 Ho AW, Wong CK, Lam CW: Tumor necrosis factor-alpha up-regulates the expression of ccl2 and adhesion molecules of human proximal tubular epithelial cells through mapk signaling pathways. Immunobiology 2008;213:533-544.

38 Watts BA, 3rd, George T, Sherwood ER, Good DW: Basolateral lps inhibits nhe3 and hcoformula absorption through tlr4/myd88-dependent erk activation in medullary thick ascending limb. Am J Physiol Cell Physiol 2011;301:C1296-1306.

-39 Abraham E: Nuclear factor-kappab and its role in sepsis-associated organ failure. J Infect Dis 2003;187:S364-369.

40 Liu SF, Malik AB: Nf-kappa b activation as a pathological mechanism of septic shock and inflammation. Am J Physiol Lung Cell Mol Physiol 2006;290:L622-L645.

-41 Kawano H, Ito T, Yamada S, Hashiguchi T, Maruyama I, Hisatomi T, Nakamura M, Sakamoto T: Toxic effects of extracellular histones and their neutralization by vitreous in retinal detachment. Lab Invest 2014;94:569-585.

-42 Ha H, Lee JH, Kim HN, Kim HM, Kwak HB, Lee S, Kim HH, Lee ZH: Alpha-lipoic acid inhibits inflammatory bone resorption by suppressing prostaglandin e2 synthesis. J Immunol 2006;176:111-117.

43 Yamada M, Kaibori M, Tanaka H, Habara K, Hijikawa T, Tanaka Y, Oishi M, Okumura T, Nishizawa M, Kwon $\mathrm{AH}$ : Alpha-lipoic acid prevents the induction of inos gene expression through destabilization of its mrna in proinflammatory cytokine-stimulated hepatocytes. Dig Dis Sci 2012;57:943-951.

44 Zhang WJ, Frei B: Alpha-lipoic acid inhibits tnf-alpha-induced nf-kappab activation and adhesion molecule expression in human aortic endothelial cells. FASEB J 2001;15:2423-2432. 